\title{
СУЧАСНІ ІННОВАЦІЙНО-ТЕХНОЛОГІЧНІ ПРИЙОМИ ТА ШЛЯХИ ПОЛІПШЕННЯ ВИВЧЕННЯ ЗАГАЛЬНИХ ПРИНЦИПІВ ТРАНСПЛАНТОЛОГІЇ ЛІКАРЯМИ-ІНТЕРНАМИ ЗА ФАХОМ "ВНУТРІШНІ ХВОРОБИ"
}

\author{
Я. О. Попович
}

\author{
ДВНЗ “Івано-Франківськийнаціональниймедичний університет”
}

\section{MODERN INNOVATION AND TECHNOLOGICAL METHODS AND WAYS OF IMPROVEMENT OF TRANSPLANTOLOGY GENERAL PRINCIPLES STUDY BY DOCTORS-INTERNS BY SPECIALTY "INTERNAL MEDICINE"}

\section{SHEI "Ivano-Frankivsk National Medical University"}

Ya. O. Popovych

\begin{abstract}
У роботі узагальнено досвід кафедри терапії і сімейної медицини ІФНМУ за фахом "Внутрішні хвороби", вивчення інтернами загальних принципів трансплантології, впровадження й удосконалення інноваційних технологій при використанні інтерактивних методів навчання на всіх етапах навчального процесу 3 вивчення спеціальності та основ трансплантології. На етапі визначення кінцевого рівня знань використовуються: вирішення кейс-завдань, ігрові та неігрові методи модельованого навчання, а якість отриманих знань оцінюється поточним та підсумковим контролем.

This paper summarizes the experience of the Department of Therapy and Family Medicine in IFNMU by specialty "Internal Medicine", study of general principles of transplantology by interns and improvement of the innovative technologies implementation using interactive teaching methods during all the stages of the educational process in the specialty and foundations of transplantology study. At the stage of final knowledge determination such methods are used: case-solving tasks, gaming and non-gaming learning methods, and the quality of knowledge is assessed by current and final control.
\end{abstract}

Вступ. Завданням інтернатури зі спеціальності "Внутрішні хвороби" $є$ набуття широкого спектра мультидисциплінарних знань, професійних умінь і навичок за кваліфікаційною характеристикою лікарятерапевта $[1,2]$. Одним із напрямків для створення комфортних умов навчального процесу є використання інноваційних технологій i, в першу чергу, інтерактивних методів навчання $[3,4]$, які $є$ особливою системою правил організації продуктивної взаємодії між собою тих, хто навчається, і тих, хто навчає [5]. Цей метод передбачає як підвищення якості викладання теоретичного курсу з використанням сучасних технологій: проблемні лекції, лекції майстер-клас, лекції прес-конференції [4], так і практичної підготовки, де поряд з традиційними підходами - робота інтерна 3 хворими, відшліфування ним майстерності визначення патологічних симптомів та ознак, широко застосовують технології ситуаційного навчання

() Я. О. Попович (кейс-метод, імітацію рольових ігор) $[4,5]$. Не менш важливою $є$ правильна організація самостійної роботи інтерна (CPI) з вивчення й оволодіння окремими позааудиторними питаннями теми (історичні віхи розвитку трансплантології, регенеративно-пластичної медицини, основ клітинно-тканинної трансплантології) із залученням низки інноваційних технологій: використання інтернет-мережі, електронних варіантів наробок кафедри, та кафедри хірургії № 1 медичного факультету з використання клітин підшлункової залози новонароджених поросят, фетальних тканин i кріопрепаратів кордової крові в лікуванні синдрому діабетичної стопи і сприяння до участі інтернів у науково-дослідницькій роботі [6].

Трансплантація органів в лікуванні хворих з безнадійною патологією в найближчі роки становитиме 50 \% усіх операцій світової хірургії. Уже сьогодні у світі якісно проживає 1 млн людей $з$ трансплантованими органами, в Україні всього 750 осіб. Це, за оцінкою ВООЗ, свідчить про дуже низький рівень ме- 
дичної допомоги населенню країни, та необізнаність широкого загалу лікарів з сучасним досягненням світової трансплантології в протоколах лікування критичних стадій захворювань життєво важливих органів.

Мета-засвоїти основні принципи правового регулювання і нормативно-директивні документи, що регулюють діяльність, пов'язану з трансплантацією, розвиток трансплантології на сучасному етапі, загальні принципи, методи, завдання та проблеми. Тактика підготовки пацієнтів та підбору реципієнтів до трансплантації, лікувальна і супресорна терапія, диспансеризація їх у післяопераційному та віддаленому періодах.

Основна частина. Підготовка лікарів-інтернівтерапевтів проводиться за індивідуальними навчальними планами, які розробляються на підставі типового (робочого) навчального плану й уніфікованої програми інтернатури. Програма складається з трьох блоків: "Внутрішні хвороби”, “Суміжні дисципліни” та “Додаткові програми”, які у свою чергу поділяються на розділи, що складаються з тем дисципліни. На додаткові програми виділено 91 годину з включенням викладання медичної генетики, клінічної імунології, паліативної допомоги, основ первинної профілактики, прикладної медичної інформатики, основ трансплантології, протидії насильству в сім'ї.

Трансплантологія - вчення про використання органів, тканин і клітин людей і тварин та пересадження їх хворим з метою зцілення, особливо з безнадійними захворюваннями. Наказом MO3 № 311 від 17 червня 2004 року “Про викладання трансплантології у вищих навчальних медичних закладах та закладах післядипломної освіти" регламентовано введення загальноосвітньої підготовки з трансплантології в обсязі 28 годин для лікарів-інтернів усіх лікувальних спеціальностей. Основною метою цієї підготовки є створення умов для широкого втілення трансплантації органів у лікуванні хворих з термінальними стадіями захворювань [7].

Головна мета інноваційної освіти - забезпечення та розвиток творчого потенціалу людини, а також їі всебічний розвиток. У перекладі з грецької мови "inovatio" означає оновлення, новизна, зміна. Цим умовам відповідає використання інтерактивних методів навчання. Методи інтерактивного навчання можуть використовуватися на різних етапах навчального процесу:

І етап - первинне оволодіння знаннями. Це можуть бути проблемна лекція, евристична бесіда, навчальна дискусія та ін.
II етап - контроль знань (закріплення). Можуть бути використані такі методи, як: колективна розумова діяльність, тестування.

III етап - формування професійних умінь, навичок на основі знань і розвиток клінічного мислення, можливе використання модельованого навчання, ігрові й неігрові методи.

Інтерактивні методи відіграють важливе значення на всіх етапах навчання. Проте при вивченні загальних принципів трансплантології особливого значення вони набувають на етапі формування професійних умінь та навичок у процесі курації хворих $з$ хронічною патологією серця, печінки, нирок, легень як перспективних реципієнтів для трансплантації. Результатом цього етапу є вироблення клінічного мислення: вміння формування діагнозу, алгоритму лікування і використання методу трансплантації донорського органа в протоколі лікування термінальних стадій захворювання, що піддається методам трансплантації [7].

Щорічно у світі виконують десятки тисяч трансплантацій різних органів, тканин і клітин з максимальною протяжністю життя до 25 років. Трансплантаційна активність у світі за 2008 рік, за даними ВООЗ, складала: 100640 - органних трансплантацій або 10 \% від необхідних. На сьогодні в Україні функціонує 7 центрів органної трансплантації, однак за рік виконується всього 100-117 трансплантацій органів. Потреба в трансплантації органів для України: 15002000 - серця, стільки ж печінки, 2500 - нирок, 2000 поєднаних трансплантацій підшлункової залози і нирки. В Україні не втілена система трансплантат-координації. Застосування цієї системи дозволить збільшити кількість потенційних донорів [7].

На кафедрі терапії і сімейної медицини ІФНМУ навчання інтернів-терапевтів за фахом "Внутрішні хвороби" загальних принципів трансплантології здійснюється за типовою програмою з дисципліни “Внутрішні хвороби” (2013 р.), розробленою співробітниками опорної кафедри терапії і сімейної медицини ІФНМУ. Навчальний план і програма затверджені на засіданні Координаційної науковометодичної ради з післядипломної освіти МО3 України від 30 травня 2013 року. За цією програмою кафедрою розроблена робоча програма, згідно з якою на 2 році навчання інтерни вивчають та засвоюють тему поспіль двох днів навчання (14 годин), із яких: 2 години - лекція, 10 годин - практична лікарська діяльність та 2 години - практичний семінар.

Теоретична підготовка інтернів здійснюється під час лекції, практичних занять та самостійної роботи з вивчення теми. При проведенні лекції нами широко 
застосовуються такі методи “інформаційного повідомлення", як: аудіовізуальні презентації, відеофільми техніки трансплантації, графіки, інтегральні схеми пересадки окремих органів, відео- й мультимедійні презентації показань та протипоказань до трансплантації того чи іншого органа, методів трансплантації, здійснення тактики підбору реципієнт - донор, супресивна терапія, етапи реабілітації та диспансеризації осіб із трансплантованими органами. Поєднання коментарів лектора $з$ відеоінформацією та анімацією значно мотивує увагу слухачів до викладання матеріалу за темою. Досить цінним під час лекції є презентація відео чи мультимедійних преференцій, діагностики та лікування окремих пацієнтів з практики лектора. Подальше засвоєння лекційного матеріалу проходить у вигляді співбесіди в діалоговому режимі (питання - відповідь). Таким чином, при викладанні теоретичного матеріалу ми переважно використовуємо дидактичні засоби навчання, варіантом якого $є$ проблемна лекція, що створює певні ситуації і залучає слухачів до їх вирішення. Така методика, за даними анкетування інтернів, дає їм можливість швидше і якісніше засвоїти тему, а рівень збережених знань становив $60-70 \%$, тоді як при традиційному викладенні $25-30 \%$. Цьому також сприяло надання їм лекційних матеріалів на електронних носіях, щоуможливлює в будь-який час протягом 15-20 хвилин оновити в пам'яті надану інформацію.

Засвоєння теоретичного матеріалу на практичних заняттях проводять також із залученням інтерактивних методик: імітаційних ділових ігор, різних видів дискусій, семінару-тренінгу, а за допомогою кейсметоду (активного проблемно-ситуаційного аналізу) - вирішенням конкретних завдань-ситуацій. Не менш важливим на початку заняття $\epsilon$ експрес-метод тестового контролю засвоєння теми в домашніх умовах шляхом вирішення тестів, кейс-завдань кожним інтерном. Особливу увагу приділяємо основам трансплантаційної імунології: головний комплекс гістосумісності (NLA), визначення серологічно залежних NLA (A,B,C,D,DR). Крос-матч-реакція сумісності лімфоцитів донора з сироваткою реципіснта для визначення цитотоксичних антитіл проти NLA антигенів; проблеми відторгнення органів, класифікації iï: за часом (надгостре, гостре, прискорено гостре); за морфологічними типами (клітинне, гуморальне (судинне), клітинно-гуморальне). Не менш важливим $\epsilon$ ознайомлення інтернів із сучасними схемами імуносупресивної терапії: сандіммун неорал, симулект, міфортік, селлсепт, зенапакс. I на кінець, найбільш важливим у загальноосвітній підготовці основам трансплантології інтернів $є$ усвідомлення ними показань і підбору реципієнтів до лікування їх методом трансплантації, та реабілітація в ранніх та віддалених післяопераційних термінах.

Крім цього, засвоєння теми відбувається шляхом дискусії і відповідей на окремі запитання, висвітлених у методичних вказівках для інтернів. Після аудиторного засвоєння теоретичних основ теми наступним етапом $є$ засвоєння практичних навичок біля ліжка тематичного хворого, де інтерни проводять збір анамнезу та фізикальні методи загальнотерапевтичного обстеження хворих з патологією серця, печінки, нирок, легень, ендокринною патологією, інтерпретують лабораторно-інструментальні дані обстеження.

Технології клітинної трансплантації інтерни вивчають на базі філії державного підприємства "Міжвідомчий науковий центр кріобіології та кріомедицини" НАН, АМН та МОЗ України (директор канд. мед. наук Я. О. Попович), де засвоюють технологію пересадки клітин і тканин у підшкірну основу; алгоритм застосування препаратів кордової крові (Кріоцел-кріокорд , Кріоцел-гемокорд), фрагментів плаценти (Платекс плацентарний)у лікуванні нагнійнозапальних ускладнень синдрому діабетичної стопи, хронічного недомагання, кардіопатології, ендокринної патології (цукрового діабету). Досить важливим у структурі навчання є оцінка якості отриманих знань та вмінь при проведенні поточного контролю на практичних заняттях кейс-завдань кожним інтерном, для чого нами розроблено 20 кейс-ситуаційних завдань теми.

Таким чином, вивчення загальних принципів трансплантології, методів, завдань та проблем ії, тактики підготовки пацієнтів до трансплантації, реабілітації та ведення пацієнтів у післяопераційному та віддаленому періодах заслуговує на подальше вдосконалення, що суттєво сприятиме підвищенню якості отриманих теоретичних знань і необхідних практичних навичок інтернами та наближає процес навчання до вирішення актуальних проблем і вимог сучасності.

Висновок. Інтерактивні, інноваційні методи підвищують ефективність та результативність навчання та їх використання на етапах навчального процесу. Особливе значення вони набирають при роботі інтернів із хворими і формуванні професійних вмінь та навичок та в розумінні необхідності більш широко застосовувати сучасні досягнення трансплантології в лікуванні безнадійних хворих у термінальних стадіях захворювань життєво важливих органів. 


\section{Література}

1. Удосконалення засвоєння практичних навичок і методик студентами та лікарями-інтернами - важлива складова кадрової перебудови первинної ланки медичної допомоги населенню України / О. П. Волосовець, Ю. С. П'ятницький, I. С. Вітенко [та ін.] // Медична освіта. -2012. -№ 3. - С. 5-7.

2. Ковальчук Л. Я. Новітні шляхи вдосконалення підготовки фахівців у Тернопільському державному медичному університеті імені І. Я. Горбачевського / Л. Я. Ковальчук // Медична освіта. - 2010. - № 2. - С. 27-30.

3. Aronson L. Twelve tips for teaching reflection at all level of medical education / L. Aronson // Med. Teacher. -2011. Vol.33(3).-P.200-205.

4. Використання інтерактивних методів навчання при вивченні основ внутрішньої медицини / О. С. Хухліна, Л. В. Каньовська, О. С. Воєвідка [та ін.] // Матеріали Всеукраїнської навчально-наукової конференції, присвяченої 55-річчю Тернопільського державного медичного універ- ситету імені І. Я. Горбачевського МОЗ України “Впровадження нових технологій за кредитно-модульної системи організації навчального процесу ВМ(Ф)НЗ III-IV рівнів акредитації”, м. Тернопіль, 26-27 квітня 2012 р.-Тернопіль : Укрмедкнига, 2012.-C. 415-416.

5. Solomon P. Student perspectives on patient educators as facilitators of interprofessional education / P. Solomon // Med.Teacher.-2011. - Vol. 33, № 10.-P. 851-853.

6. Попович Я. О. Препарати кріоплацентарного комплексу в корекції оксидантного стресу при хірургічному лікуванні хворих на синдром діабетичної стопи / Я. О. Попович, А. Г. Шевчук, М. Д. Василюк// Трансплантолонтология. -2007.- Т. 9, № 1.-С. 224-228.

7. Денисов В. К. Проблемы и перспективы общеобразовательной подготовки врачей по специальности “Трансплантология" в медицинских вузах / В. К. Денисов // Трансплантологія. -2004. - Т. 7, № 3.-С. 13-19.

Отримано 02.07.14 